\title{
Kajian Pendapatan Agroindustri Tortila Di Kecamatan Insana Barat Kabupaten Timor Tengah Utara
}

\author{
Marsianus Falo ${ }^{a}$, Yosefina Marice Fallo ${ }^{\mathrm{b}}$ \\ ${ }^{a}$ Fakultas Pertanian, Universitas Timor, Kefamenanu, TTU - NTT, Indonesia. \\ ${ }^{b}$ Fakultas Pertanian, Universitas Timor, Kefamenanu, TTU - NTT, Indonesia.
}

\section{Article Info}

Article history:

Received 12 Januari 2016

Received in revised form 25 Januari 2016

Accepted 23 Maret 2016

\section{Keywords:}

Agroindustri

Tortila

Pendapatan

\section{Abstrak}

Pemberdayaan kelompok tani merupakan upaya yang harus dilakukan untuk meningkatkan produktivitas kelompok tani tersebut yang Penelitian ini dilakukan di Kelompok tani Basam Tasa Kelurahan Atmen Kecamatan Insana Barat Kabupaten Timor Tengah Utara sejak bulan Februari sampai bulan April 2014 dengan tujuan: 1) Untuk mengetahui gambaran proses produksi tortila pada Kelompok Tani Basam Tasa di Kecamatan Insana Barat Kabupaten Timor Tengah Utara, 2) Untuk mengetahui pendapatan yang diperoleh dari usaha agroindustri tortila pada Kelompok Tani Basam Tasa di Kecamatan Insana Barat Kabupaten Timor Tengah Utara. Metode yang digunakan adalah metode survei. Untuk menjawab tujuan pertama dan kedua digunakan metode deskriptif dan pendapatan, Hasil penelitian menunjukkan : 1) Dalam proses pengolahan tortila, tahapannya: a.) Jagung yang digunakan adalah jagung kuning yang sudah dijemur kering. b) Jagung yang telah ditumbuk, dicuci kemudian dimasak. c). Jagung yang telah masak digiling dengan menggunakan blender sampai halus. d. Pencetakan dilakukan saat adonan yang dikukus sudah berubah warna. e) adonan yang telah dicetak dijemur sampai setengah kering, lalu dipotong persegi panjang dan di jemur lagi sampai kering. f). Tortila yang sudah kering dikemas untuk di jual. 2) Berdasarkan analisis pendapatan dapat diketahui bahwa: Produksi tortila adalah jumlah fisik tortila yang dihasilkan mencapai 2790 bungkus dengan rata-rata produksi yang diperoleh mencapai 174,375 bungkus bahan baku yakni jagung sebanyak $557 \mathrm{~kg}$. Ratarata penerimaan Rp.1.064.250 dengan variasi penerimaan tertinggi adaalah Rp.1.290.000 dan penerimaan terendah Rp. 900.000. Berdasarkan hasil penelitian diketahui bahwa rata-rata pendapatan adalah Rp.556.938/responden/bulan dengan variasi pendapatan tertinggi adalah Rp.640.000 dan pendapatan terendah adalah Rp.384.500. @2016 dipublikasikan oleh Agrimor.

\section{Pendahuluan}

Pembangunan pertanian merupakan bagian integral dari pembangunan ekonomi nasional, dimana pertumbuhan ekonomi menjadi orientasi utama masyarakat yang bersifat struktural di Pedesaan kurang diperhatikan dalam menentukan kebijakan ekonomi pertanian yang bertujuan untuk meningkatkan produksi dan produktivitas pertanian baik untuk dikonsumsi sekaligus sebagai bahan baku agroindustri.

Agroindustri adalah bagian dari Agribisnis yang memproses dan mentransformasikan hasil pertanian menjadi barang setengah jadi yang langsung di konsumsi dan bahan baku agroindustri yang digunakan dalam proses produksi. Menurut Austin (1992) agroindustri merupakan industri yang mengolah hasil-hasil pertanian yang mudah rusak dan tidak tahan lama serta musiman. Kebutuhan akan pangan ini berlangsung sepanjang waktu, sehingga dengan adanya industri pengolahan produk pertanian dapat menyediakan kebutuhan bagi konsumen.

Salah satu agroindustri yang dikembangkan adalah agroindustri tortila Tortila berasal dari bahasa Spanyol yang artinya kerupuk jagung. Tortila merupakan salah satu bentuk olahan jagung yang mempunyai kandungan gizi cukup baik. Pengolahan tortila ini sangat sederhana dan mudah dipahami. Kandungan gizi tortila atau kerupuk jagung meliputi lemak, serat, protein dan karbohidrat. Komposisi kimia jagung setelah diolah menjadi kerupuk jagung.

Pengembangan agroindustri tortila di Kabupaten Timor Tengah Utara relatif lamban, bahkan cenderung di tempat. Hal ini disebabkan karena usaha ini didominasi oleh industri rumah tangga yang kapasitas produknya sangat terbatas dan memiliki akses pasar yang bersifat lokal.

Kecamatan Insana Barat merupakan satu-satunya daerah yang mengembangkan agroindustri tortila. Agroindustri tortila yang dikembangkan masih bersifat tradisional, input yang digunakan masih relatif sedikit karena keterbatasan modal yang dimiliki petani serta minimnya pengetahuan petani tentang pentingnya penggunaan input yang efisien. Input yang digunakan dalam agroindustri tortila di Kecamatan Insana Barat adalah bahan baku, bahan penolong, bahan bakar, dan tenaga kerja, dan modal.

Agroindustri tortila yang dikembangkan di Kecamatan Insana Barat setiap tahun berfluktuasi yaitu dari tahun 2008 sampai tahun 2013 karena ketersediaan bahan baku yang cukup kecuali pada tahun 2012. Leki (1994) mengatakan bahwa agroindustri merupakan industri yang mengolah hasil-hasil pertanian menjadi bahan setengah jadi maupun bahan jadi yang siap dikonsumsi. Menurut Soekartawi (2002) agroindustri adalah salah satu cabang industri yang mempunyai kaitan erat dan langsung dalam pengolahan hasil-hasil pertanian.Pengamatan di lapangan menunjukkan bahwa pada tahun 2012 ketersediaan bahan baku (jagung) sangat sedikit disebabkan karena gagal panen dan permintaan konsumen juga berkurang. Oleh karena itu, ketersediaan Bahan baku harus diperhatikan sehingga dapat meningkatkan produksi.

Menurut Soekartawi (1995) tersedia produksi dipengaruhi oleh berbagai faktor produksi antara lain lahan, tenaga kerja, modal, dan manajemen. Agroindustri di lokasi penelitian membutuhkan sejumlah input seperti tenaga kerja yang terampil, modal yang cukup dan manajemen yang baik namun kenyataannya penggunaan input belum optimal. Oleh karena itu, untuk meningkatkan produksi tortila guna untuk meningkatkan pendapatan maka semua anggota kelompok harus berupaya untuk memanfaatkan input yang di miliki. Berdasarkan uraian latar belakang maka penelitian ini merampungnya menjadi dua permasalahan yang ingin ditelit yakni 1) bagaimana gambaran usaha produksi tortilla dan berapa besar pendapatan yang diterima dari usaha tortilla.

\section{Metode}

Penelitian ini telah dilaksanakan pada Kelompok Tani Basam Tasa di Kecamatan Insana Barat, Kabupaten Timor Tengah Utara pada bulan Februari sampai dengan bulan April 2014. Penentuan sampel menggunakan metode sensus yaitu semua anggota agroindustri tortila di Kelompok Tani Basam Tasa yakni sebanyak 16 orang. Metode yang digunakan dalam pengumpulan data adalah metode survei. Jenis data yang dikumpulkan berupa data primer dan data sekunder. Analisis Menggunakan analisa data deskriptif dan analisis pendapatan (Soekartawi 1995)

\section{Hasil dan Pembahasan}

\subsection{Gambaran Proses Produksi Tortila}

Tortila atau kerupuk jagung merupakan salah satu bentuk olahan jagung yang berasal dari Meksiko. Proses pengolahan tortila ini sangat sederhana dan mudah dibuat dengan menggunakan peralatan rumah tangga (Broe, 2008).

Tortila adalah salah satu bentuk olahan bahan pangan yaitu jagung. Tortila berasal dari bahasa Spanyol yang artinya jagung. Pada mulanya tortila merupakan produk olahan jagung yang berbentuk dadar (bulat, tipis, dan panjang), dan kemudian berkembang menjadi produk olahan kering berbentuk chips yang kenal dengan nama kerupuk jagung. Dalam proses pengolahan tortila, tahap-tahap yang harus dilalui antara lain :

1. Jagung

Jagung yang digunakan untuk pembuatan tortila atau kerupuk jagung adalah jagung kuning yang sudah dijemur kering. Jagung pipilan kering in dibersihkan, kemudian dihaluskan dengan cara ditumbuk dengan tujuan untuk memisahkan kulit ari dengan isinya. Alat yang digunakan adalah lesung dan alu. Saat proses penumbukan, jagung yang ada dalam lesung diisi air. Fungsi air ini adalah untuk melarutkan kulit jagung sehingga bisa terpisah dari isinya.

2. Pemasakan

Jagung yang telah ditumbuk, dicuci dan dimasukan kedandang yang sudah berisi air untuk dimasak. Proses pemasakan selama 30 menit. Bahan bakar yang digunakan adalah kayu api. Jika jagung yang dimasak sudah lunak, airnya ditiriskan selama 10 menit dan dicampur dengan bawang putih yang telah diiris untuk digiling. Bawang yang digunakan untuk $1 \mathrm{~kg}$ jagung adalah 30 siung. 3. Penggilingan

Jagung yang telah masak digiling dengan menggunakan blender sampai halus. Setelah proses penggilingan selesai, jagung yang sudah halus di campur kanji dan gula pasir diaduk sampai merata dan dikukus lagi sampai adonan berubah warna. Jumlah kanji yang digunakan untuk $1 \mathrm{~kg}$ jagung sebesar $250 \mathrm{gr}$ gula pasir sebesar 2 sendok makan, dan air secukupnya.

4. Pencetakan

Proses pencetakan dilakukan saat adonan yang dikukus sudah berubah warna. Pencetakan ini dilakukan dengan menggunakan botol yaitu adonan dibentang di meja yang beralas plastik dan digilas sampai adonan berukuran 1,5 $\mathrm{mm}$. Adonan yang telah digilas digaris menggunakan batang sendok sesuai selera. Tujuan dari penggarisan ini adalah untuk mempermudah pemotongan. 5. Pengeringan

Untuk mendapatkan hasil yang baik, adonan yang telah dicetak dijemur sampai setengah kering, lalu dipotong persegi panjang dan di jemur lagi sampai kering. Maka jadilah tortila atau kerupuk jagung. Proses pengeringan dilakukan dengan menggunakan cahaya matahari. Waktu yang dibutuhkan untuk pengeringan adalah 2 jam. Jika musim hujan, proses pembuatan tortila menurun. Hal ini disebabkan karena proses penjemuran cukup memakan waktu yaitu 2-3 hari. 


\section{Pengemasan}

Tortila yang sudah kering dikemas untuk di jual. Pengemasan ini dilakukan dengan menggunakan plastik bening dengan tujuan untuk melindungi tortila agar tidak mudah rusak. Tortila yang sudah dikemas disimpan pada tempat yang aman. Bagan proses pembuatan tortila adalah sebagai berikut :

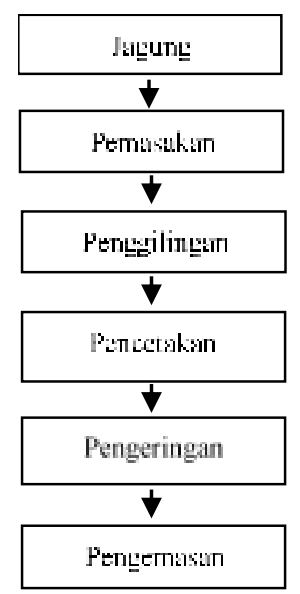

Gambar 1: Bagan proses produksi tortila di Kelompok Tani Basam Tasa, 2014.

\subsection{Gambaran Penggunaan Input}

Responden di lokasi penelitian dalam melakukan pengolahan tortila, inputinput yang digunakan adalah bahan baku, bahan penolong, bahan bakar, tenaga kerja, dan bahan penolong lainnya.

1. Bahan baku (jagung)

Bahan baku yang dimaksud adalah jagung kuning, yang diperoleh dari petani di desa lain. Jumlah jagung yang digunakan sebanyak $557 \mathrm{~kg} /$ tahun. Hal ini menentukan tingkat pencapaian produk tortila yang dihasilkan. Rata-rata jagung yang digunakan adalah $34,8125 \mathrm{~kg} /$ responden dengan jumlah jagung tertinggi adalah $42 \mathrm{~kg}$ dan terendah adalah $27 \mathrm{~kg}$.

2. Bahan penolong (kanji)

Bahan penolong yang digunakan dalam pengolahan tortila adalah kanji. Kanji berfungsi sebagai bahan perekat dan pelicin sehingga mudah masuk dalam plastik. Rata-rata kanji yang digunakan dalam pengolahan tortila adalah $3 \mathrm{~kg} /$ responden dengan jumlah kanji tertingi adalah $4 \mathrm{~kg}$ dan jumlah kanji terendah adalah $2 \mathrm{~kg}$.

3. Bahan bakar (kayu api)

Bahan bakar yang digunakan adalah kayu api. Bahan bakar ini diproleh dari petani yang menjual kayu api. Rata-rata penggunaan kayu api adalah $16,0625 \mathrm{ikat} /$ responden dengan jumlah tertinggi adalah $20 \mathrm{ikat}$ dan terendah adalah 13 ikat.

4. Tenaga kerja

Berdasarkan hasil penelitian, tenaga kerja yang digunakan dalam proses pengolahan tortila di Kelompok Tani Basam Tasa adalah anggota kelompok sendiri. Secara keseluruhan rata-rata penggunaan curahan tenaga kerja agroindustri tortila di Kecamatan Insana Barat adalah sebesar 34,28625 HKO.

5. Bahan penolong lainnya (gula pasir, bawang putih dan label)

Bahan penolong lain yang digunakan dalam pengolahan tortila adalah gula pasir, bawang putih dan label. Rata-rata bahan penolong lain yang digunakan sebesar Rp.123,250/ responden dengan jumlah tertinggi adalah Rp. 200.000 dan terendah adalah Rp. 175.000

6. Modal

Modal yang dimaksud adalah biaya-biaya yang dikeluarkan meliputi biaya bahan baku, biaya bahan penolong, biaya bahan bakar, biaya tenaga kerja, biaya gula pasir, biaya bawang putih, dan biaya label, sedangkan biaya peralatan dan biaya transportasi tidak diperhitungkan karena merupakan biaya bersama. Total modal yang digunakan adalah sebesar Rp.12.185.000 dengan rata-rata Rp. $761.562,5$.

\subsection{Analisis Pendapatan}

1. Gambaran Produksi

Produksi tortila adalah jumlah fisik tortila yang dihasilkan. Berdasarkan hasil perhitungan rata-rata produksi yang diperoleh mencapai 2790 bungkus dengan rata-rata produksi yang diperoleh mencapai 174,375 bungkus bahan baku yakni jagung sebanyak $557 \mathrm{~kg}$.

2. Penerimaan

Berdasarkan hasil penelitian diketahui bahwa rata-rata penerimaan Rp.1.064.250 dengan variasi penerimaan tertinggi adaalah Rp.1.290.000 dan penerimaan terendah Rp. 900.000. Perbedaan penerimaan disebabkan karena rata-rata produksi yang dihasilkan berbeda-beda tergantung kemampuan petani.

3. Biaya Produksi

Menurut Slat (1984) biaya merupakan nilai uang dan alat-alat produksi yang dibebankan rumah tangga untuk perusahaan pada proses produksi selanjutnya. Berdasarkan hasil penelitian rata-rata biaya produksi adalah $\mathrm{Rp}$ 489.313/ responden. Biaya produksi terdiri dari biaya tetap dan biaya variabel. Biaya tetap merupakan biaya yang besar kecilnya tidak tergantung pada besar kecilnya produksi. Sedangkan biaya variabel adalah biaya yang besar kecilnya berhubungan langsung dengan besarnya produksi. Biaya variabel dalam penelitian ini terdiri dari biaya bahan baku, biaya bahan penolong, biaya bahan bakar, biaya tenaga kerja. Biaya tetap tidak diperhitungkan karena merupakan biaya bersama (joint cost) .

4. Pendapatan

Berdasarkan hasil penelitian diketahui bahwa rata-rata pendapatan adalah Rp.556.938/ responden dengan variasi pendapatan tertinggi adalah Rp.640.000 dan pendapatan terendah adalah Rp. 384.500

\section{Simpulan}

Berdasarkan hasil penelitian, gambaran kegiatan Agroindustri Tortila di Kecamatan Insana Barat meliputi beberapa tahapan proses produksi tortila yaitu pemasakan, penggilingan, pencetakan, pengeringan, pengemasan dan pemasaran. Hasil penelitian terhadap pendapatan agroindustry tortilla diketahui bahwa rata-rata pendapatan adalah Rp.556.938/responden/tahun dengan variasi pendapatan tertinggi adalah Rp.640.000 dan pendapatan terendah adalah Rp.384.500.

\section{Pustaka}

Austin. J.E. 1992. Agroindustrial Project Analysis. The Jhon Hopkin University Prss. London.

Broe. 2008. Agribisnis jagung. CV. Pustaka Grafika. Bandung.

Leki S.1994. Beberapa Pengertian Tentang Agribisnis. Institut. Bogor. Slat. 1984. Pengantar perusahaan.Rajawali Pers. Jakarta.

Soekartawi, 1995 . Analisis Usahatani. UI-PRESS. Jakarta .

Soekartawi. 2002. Pengantar agroindustri. PT Raja Grafindo. Jakarta 